\title{
Using conjoint analysis to understand customer preferences in customized low-income housebuilding projects
}

\author{
O uso da analise conjunta para compreender as \\ preferências dos clientes de projetos de habitação de \\ baixa renda
}

\section{Cynthia dos Santos Hentschke \\ Patricia André Tillmann \\ Carlos Torres Formoso \\ Vera Lúcia Milani Martins \\ Marcia Elisa Soares Echeveste}

${ }^{1}$ Cynthia dos Santos Hentschke

${ }^{1}$ Universidade Federal do Rio Grande Porto Alegre - RS - Brasil

${ }^{2}$ Patrícia André Tillmann ${ }^{2}$ University of California San Francisco San Francisco - CA - USA

${ }^{3}$ Carlos Torres Formoso ${ }^{3}$ Universidade Federal do Rio Grande do Sul Porto Alegre - RS - Brasil

${ }^{4}$ Vera Lúcia Milani Martins 4Instituto Federal de Edução, Ciência e Tecnologia do Rio Grande do Sul Porto Alegre - RS - Brasil

${ }^{5}$ Maria Elisa Soares Echeveste 5Universidade Federal do Rio Grande do Sul Porto Alegre - RS - Brasil

Recebido em 24/03/19 Aceito em 22/09/19

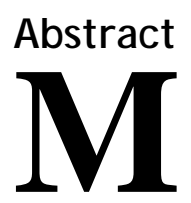

ass customization is a strategy to improve value generation for customers, by offering product variety and, at the same time, maintaining costs and delivery time to an acceptable level. A key problem for applying this strategy in the housebuilding sector is the definition of the solution space, i.e. the range of product alternatives that will be offered. This paper proposes an adaptation of conjoint analysis to identify customer preferences regarding customizable attributes in low-cost housing projects. The utility of this adaptation is illustrated by a case study, which was carried out in a construction company that had delivered low-income housing projects, and offered some degree of product flexibility. Results indicate that this technique was effective to understand customers' preferences out of a range of housing attributes, by providing a ranking of those attributes chosen by customers. Therefore, this technique can support decision-making when dealing with tradeoffs between customers' preferences, product flexibility and costs, which is an important concern for companies that deliver customized housing units.

Keywords: Conjoint analysis. Customer’s preference. Low-income housing. Controlled customization.

\section{Resumo}

A customização em massa é uma estratégia para melhorar a geração de valor para os clientes, oferecendo variedade de produtos e, ao mesmo tempo, mantendo os custos e o prazo de entrega em um nível aceitável. Um problema importante para a aplicação dessa estratégia no setor de produção habitacional é a definição do espaço da solução, ou seja, a variedade de alternativas de produtos a serem oferecidos. Este artigo propõe uma adaptação da análise conjunta para identificar as preferências dos clientes em relação aos atributos customizáveis em empreendimentos habitacionais de baixa renda. A utilidade dessa adaptação é ilustrada em um estudo de caso, o qual foi realizado em uma empresa de construção que entrega empreendimentos habitacionais de baixa renda e oferece algum grau de flexibilidade do produto. Os resultados indicam que essa técnica foi eficaz para compreender as preferências dos clientes dentre diversos atributos de moradia, indicando um ranqueamento dos atributos escolhidos pelos clientes. Consequentemente, essa técnica pode dar suporte a tomada de decisões ao considerar os trade-offs entre as preferências dos clientes, a flexibilidade e os custos do produto, um fator importante a ser considerado por empresas que entregam unidades habitacionais customizadas.

Palavras-chave: Análise conjunta. Preferências dos Clientes. Habitação de baixa renda. Customização controlada. 


\section{Introduction}

In Brazil, several low cost housebuilding programs have been promoted by the Federal Government in recent years with the aim of reducing the housing shortage (KOWALTOWSKI; GRANJA, 2011). Similarly to other developing countries, most of those programs have been conceived considering mass production ideas: repetition and standardization in large scale have been used as a strategy to reduce project costs (KOWALTOWSKI et al., 2018; CASTRO; SHIMBO, 2011; HENTSCHKE et al., 2014), and to simplify contractual and financial procedures (FORMOSO; LEITE; MIRON, 2011). A major drawback of this strategy is the lack of effectiveness in dealing with the increasing diversity in household profiles.

In fact, previous studies on the assessment of value generation in housing projects indicate that standard products often lead to often lead to dwellers' dissatisfaction (FORMOSO; LEITE; MIRON, 2011; GRANJA et al., 2009; KOWALTOWSKI; GRANJA, 2011; SILVA et al., 2012). Furthermore, according to Kowaltoski and Granja (2011), the fact that some housing programs prescribe minimum requirements for internal spaces and product specification have encouraged the industry to deliver affordable standard products, without much concern with value generation.

In this context, the application of Mass Customization (MC) can potentially increase the value of housing, by delivering products that fulfil specific requirements of different customers through flexible process and organizational structures with delivery times and costs similar to mass production (PINE II, 1994; SILVEIRA; BORENSTEIN; FOGLIATTO, 2001). Several cases have been reported in the literature, in which some practices associated to MC have been successfully applied by housebuilding companies from different countries, including U.K. (BARLOW, 1998; BARLOW; OZAKI, 2003), Mexico (NOGUCHI; HERNÁNDEZ-VELASCO, 2005), Brazil (ROCHA, 2011; TILLMANN; FORMOSO, 2008), and especially Japan (LINNER; BOCK, 2012).

MC is a strategy that has emerged in the manufacturing industry, which enables companies to offer products that fulfil the needs of customers that have different requirements (DAVIS 1987; PINE II, 1994; PILLER 2004). It is based on the assumption that product variety must be limited, and should be determined from a deep understanding of customer demand (FOGLIATTO; DA SILVEIRA; BORENSTEIN, 2012; FRUTOS; BORENSTEIN, 2004). In other words, it is important to know which are the relevant attributes for customers when customizing a product, and to find a balance between flexibility and efficiency (FOGLIATTO; DA SILVEIRA; BORENSTEIN, 2012; SCHOENWITZ et al., 2017; SCHOENWITZ; NAIM; POTTER, 2012). Furthermore, customers should not be overwhelmed with a large number of options, in order to avoid confusion and dissatisfaction. This is particularly important in housing, due to the large number of customizable attributes, which can make the decision making process for customers highly complex (FRUTOS; BORENSTEIN, 2004; HENTSCHKE et al., 2014; NAHMENS; BINDROO, 2011; SCHOENWITZ; NAIM; POTTER, 2012). By knowing which are the valueadding attributes for customers and the limits of production capacity, companies can establish a limited solution space so that each customer does not need to spend much effort to choose the most suitable alternative (SALVADOR; HOLAN; PILLER, 2009; VON HIPPEL, 1998).

Therefore, understanding individual needs of different customers is a major challenge in MC, and there are some techniques, generally known as discrete choice methods, that can be used to identify customization preferences (FERGUSON; OLEWNIK; CORMIER, 2014; FOGLIATTO; DA SILVEIRA, 2008). Conjoint analysis is one of those methods, and it seems to be suitable for this problem due to its ability to represent customers' preferences diversity, although adaptations are often necessary to overcome the limitations of those techniques when applied to situations in which complex decision-making might be necessary (FERGUSON; OLEWNIK; CORMIER, 2014), such as customization of housebuilding.

Fogliatto and Silveira (2008) suggest using the conjoint analysis method to support the definition of solution spaces in MC, based on its ability of estimating consumers' preferences and choice regarding hypothetical market alternatives, as suggested by Madden (1995) and Unterschultz, Quagrainie and Vincent (1997). Conjoint analysis provides information about the structure of consumers' preferences, which is obtained from their overall judgment of a set of alternative products, defined as a combination of levels of different attributes (GREEN; SRINIVASAN, 1978). Preferences are then given to product alternatives divided into separable attributes, which can be examined for their individual effect on choice (GERARD; SHANAHAN; LOUVIERE, 2003).

Since the Nineties, several studies have applied conjoint analysis to devise models that estimate housing preferences (BRANDLI; HEINECK, 2005; FREITAS, 2000; GRANJA et al., 2009; LOUVIERE; TIMMERMANS, 1990; MOLIN, 2011; MOLIN; OPPEWAL; TIMMERMANS, 2001; ORZECHOWSKI; ARENTZE; BORGERS, 2005). Other studies have explored the factors that affect the choice of new homes, such as customer profile, product 
attributes and previous housing experience (BRANDSTETTER et al., 2013; FREITAS; HEINECK, 2003), and also the degree of satisfaction (BRANDSTETTER, 2004). Those studies have contributed to the understanding of housing preferences of potential dwellers, producing information that can be used by housebuilding companies to develop new projects, or by urban planners (MOLIN; OPPEWAL; TIMMERMANS, 2001).

Moreover, conjoint analysis has been used to describe and predict customers' choices by estimating the demand for housing, considering a specific set of hypothetical housing product alternatives, as well as to assess the utility of different alternatives (LOUVIERE; TIMMERMANS, 1990; MOLIN; OPPEWAL; TIMMERMANS, 2001). Freitas (2000) devised a market segmentation method combining conjoint analysis technique and Chi-square automatic interaction detection (CHAID), with the aim of understanding the residential demand and preferences regarding housing typologies and their relationship with customers' profiles. Furthermore, Granja et al. (2009) suggested that conjoint analysis can be used to estimate the desired value in housebuilding projects, producing information that can improve value generation in housing provision. However, none of those studies have explored the application of conjoint analysis for understanding customer preferences in customized housebuilding projects.

This paper proposes an adaptation of conjoint analysis to identify customer preferences regarding customizable attributes, in order to support the refinement of solution spaces for low-income housebuilding projects. A case study was carried out in a housebuilding company, with the aim of testing the use of conjoint analysis for that application. Due to the cost constraints that usually exists in the low-income housing market, it is important to have data about customers' preferences to support decision-making about the solution space, so that a balance can be achieved when analysing trade-offs between efficiency and value generation.

\section{Mass customization}

The term MC was first coined by Stan Davis in 1987, referring to the strategy of reaching a larger number of customers, like in Mass Production, giving them an individual treatment, like in Craft Production (DAVIS, 1987). This concept has emerged in the late Eighties and may be viewed as a natural follow up to processes that have become increasingly flexible and optimized regarding quality and costs (SILVEIRA; BORENSTEIN; FOGLIATTO, 2001).

In MC, customizable attributes become feasible by, for instance, combining standard parts in different ways, and providing a supporting service through which customers' requirements are captured (NOGUCHI, 2005). Therefore, not only product design is important to enable the combination of different solutions, but also supporting services, which provide an adequate structure through which the customers are able to express their preferences for customizing a product. In such an environment, knowledge creation and information sharing play a key role, as the customization process depends on the ability to translate customers' demand into products and services (FERGUSON; OLEWNIK; CORMIER, 2014; SILVEIRA; BORENSTEIN; FOGLIATTO, 2001).

Previous studies have provided evidences that consumers are willing to pay a premium price for a product that better fulfils their needs than to purchase the best standard product attainable (DU; TSENG, 1999; PILLER, 2004). Therefore, organizations should focus on identifying what generates value to customers to support the definition of the solution space, so that an adequate customized product can be delivered (GILMORE; PINE II, 1997; HART, 1995; PILLER, 2004; SQUIRE et al., 2004). Woodruff (1997) argues that the perceived value by consumers is based on the comparison of what is received (e.g. utility, quality, delivery time) and what he or she gives up in order to acquire and use a product (e.g. price, time, effort). In summary, mass customizing a product means allowing consumers to choose from a range of possible benefits (or product characteristics) that they is willing to pay for, according to their cognitive and economic limits, therefore increasing the perceived value (GILMORE; PINE, 2000; FERGUSON; OLEWNIK; CORMIER, 2014).

According to Fogliatto and da Silveira (2008), research on MC has progressed from an initial focus on the manufacturing capabilities to produce variety at low cost to a broader emphasis on supply chain coordination and customer involvement in the process of designing, producing, and delivering MC products and services. Moreover, much research has been dedicated to facilitate customers' involvement in the process of defining a mass customized product (FERGUSON; OLEWNIK; CORMIER, 2014; FOGLIATTO; DA SILVEIRA, 2008; FOGLIATTO; DA SILVEIRA; BORENSTEIN, 2012). However, some core elements in the MC strategy remain unexplored, such as defining solution space and choice menu design, especially in the housing context (FOGLIATTO; DA SILVEIRA, 2008; ROCHA, 2011).

In this research study, two mass customization concepts have been emphasized. The first one is the solution space, which is the definition of the customizable attributes, how they vary, and are combined to be offered to customers (ROCHA, 2011; SALVADOR; HOLAN; PILLER, 2009). The second is the choice menu, also known as customer 
interaction system, configurator, or choice board, which is used for guiding the user through the customization process, reducing the burden of choice from the customers' perspective (PILLER, 2004; SALVADOR; HOLAN; PILLER, 2009). The definition of the solution space plays a key role in the design and implementation of the choice menu.

Some previous research studies have been carried out in order to support the solution space definition and elaboration of choice menus for mass customized products (e.g. FOGLIATTO; SILVEIRA, 2008; HENTSCHKE et al., 2014), and models to evaluate customer preferences based in multi-attribute utility function (e.g. SONG; JANG; SOHN, 2009). However, despite the increasing presence of choice menus in different sectors, few studies appear to have focused on problems associated to their design and configuration (BHARATI; CHAUDHURY, 2004; PILLER, 2004; ROCHA, 2011). In this context, conjoint analysis could be used to overcome some of the difficulties faced in the definition of choice menus:

(a) difficulty to assess and to measure preferences (GREENE; ORTÚZAR, 2002);

(b) the large number of attributes and combinations increases the complexity of planning experiments (SCHOENWITZ et al., 2017); e

(c) the perception of value of those attributes may change due to the evolving family profiles or to the specific subjects under assessment (DE MEDEIROS; RIBEIRO; CORTIMIGLIA, 2016; FREITAS, 2000).

\section{Conjoint analysis}

Conjoint analysis is a technique that has emerged in the early Seventies, being deeply influenced by mathematical psychology and psychometrics (GREEN; KRIEGER; WIND, 2001; GREEN; WIND, 1975). Conjoint analysis has been used mostly by marketing and business researchers to portrays consumer's decisions realistically as trade-offs among multi-attribute products or services (GREEN; KRIEGER; WIND, 2001). It is a technique to analyse survey responses by measuring trade-offs concerning preferences and likelihood-to-buy, as well as to predict consumers' behaviour when facing changes in a product or in the introduction of new products (GREEN; KRIEGER; WIND, 2001). The knowledge created by conjoint analysis can be used to:

(a) modify attributes of existing products or services;

(b) design new versions of a product or service targeted to a specific audience; and

(c) define marketing features such as packaging, brand and promotional combinations (GREEN; KRIEGER; WIND, 2001; GREEN; WIND, 1975).

The aim of conjoint analysis is to determine factors that indicate the relative importance of each attribute or its contribution to the overall utility (GREEN; WIND, 1975; MOLIN, 2011). Even though consumers do not usually make a choice considering all alternatives, it is possible to obtain the general utility for all alternatives through preference models (GREEN; WIND, 1975). It is assumed in conjoint analysis that individuals evaluate the alternatives firstly based on the attribute levels resulting in part-worth utilities, and then they combine or sum those into the value of the product alternative or its utility, responding at an aggregate level (LOUVIERE; TIMMERMANS, 1990).

Conjoint analysis have some limitations, similarly to other techniques, such as the fact that the decomposition approach may not be suitable to all products and services, especially those in which alternatives cannot be designated by attributes (GREEN; WIND, 1975). Louviere and Timmermans (1990) highlight that a major limitation of conjoint analysis in housing is the double-edge problem of the number of attributes and levels and the use of factorial experiments to describe housing alternatives, limiting the range of possibilities to cope with the human cognitive abilities. Previous applications of conjoint analysis in housing usually discuss broadly the type of product and residential environment that are preferred by customers (FREITAS, 1995, 2000; LOUVIERE; TIMMERMANS, 1990; MOLIN; OPPEWAL; TIMMERMANS, 2001 ), but it has not been used to define solution spaces for housebuilding projects (ORZECHOWSKI; ARENTZE; BORGERS, 2005).

\section{Research method}

A case study was carried out in a small sized housebuilding company located in the Metropolitan Region of Porto Alegre, South of Brazil, which delivers projects for low-income families, most of them funded by the Federal Government.

This company was chosen due to the fact that it had a good reputation on the delivery of housing projects, and also because the strategy of customizing housing units was often adopted in some projects. In these projects, 
the company offered different sets of customizable attributes by displaying a choice menu to potential homebuyers. Moreover, the company had data available about customer satisfaction and preferences from previously customized projects. However, the relative importance of each alternative had not been systematically assessed.

The role of the company in the delivery of housing was not limited to design and construction of the housing units. Due to the necessary requirements for getting funding for low-cost housing projects, the company was also strongly involved in advertising the project and gathering groups of potential homebuyers, with the support of some realestate agencies. Once a group of homebuyers had their loans approved by the financial institution, the company could receive funding to produce a housing project. Most of the housing units were sold before or during the construction phase, after the design had been approved by the local authority.

The case study was divided into seven steps:

(a) preparation;

(b) selection of attributes;

(c) definition of attribute levels;

(d) choice of the type of measurement scale;

(e) definition of the experimental design; and

(f) data collection from a sample of potential customers;

(g) analysis and discussion of results.

The data preparation step consisted of gathering and analysing qualitative data about customer preferences with the aim of establishing a set of customizable product attributes that are relevant for customers. Then, conjoint analysis application was carried out according to the stages proposed by Molin (2011), from step (b) to (f). Subsequently, in step (g) the results were analysed and discussed. The expected outcome of this conjoint analysis application is understanding customers' preferences by analysing how they judge and chose product alternatives that provide a suitable combination of attributes.

Two main sources of data were used in the preparation step: an existing database of customer satisfaction and preferences, and semi-structures interviews with representatives of the company. The database had been organized in a previous study (TILLMANN; FORMOSO, 2008), and contained different types of data from different projects, such as:

(a) household profile;

(b) reasons why potential homebuyers have not bought a housing unit;

(c) modifications requested prior or during construction;

(d) degree of satisfaction at delivery;

(e) degree of satisfaction measured in a post occupancy evaluation; and

(f) changes made in housing units after moving.

This database contained information that was systematically collected by the company at different points in time of housebuilding projects. For instance, during the first contacts with potential homebuyers, the company collected some information about customers' profile and reasons why some of them decided not to buy a house. After houses were sold, another type of data was collected: customers' requests for changing the design of housing units. Data from customer satisfaction surveys, both at project delivery and after one year of occupancy, were also taken into consideration.

Semi-structured interviews were carried out with the company director, representatives of the design team, and representatives of the sales team. All of them were chosen for having some kind of contact with the customers, and for being familiar with the housebuilding market. A protocol was devised for the interviews, including the following main questions:

(a) Who are the company's clients?

(b) Which are the company's product best features?

(c) Which are the most common requests from customers to make a deal and buy a house?

(d) Which kind of product changes are commonly requested by the customers? 
The range of attributes (i.e. factors) and levels, are the initial steps of conjoint analysis application (GREEN; KRIEGER; WIND, 2001; LOUVIERE; TIMMERMANS, 1990), which in this research define the solution space of the hosing product. Based on the interviews carried out with representatives of the house building company and on the existing database of customer satisfaction, a set of 14 customizable attributes was defined to be considered in the application of conjoint analysis. Then, those attributes were classified into five categories and two levels were used to describe each of them: +1 indicates the presence of customized attribute in the product alternative; and -1 indicates the absence of the customized attribute in the alternative.

Subsequently, the measurement scale was defined and a stimulation method for simulating a realistic house acquisition process was deviced, considering the need to reduce respondents choice effort, without compromising the application of preference modeling. Battesini and Ten Caten (2005) proposed a two step stimulation conjoint analysis technique. The main diference of this technique in relation to other conjoint analysis approaches is the fact that respondents firstly answer according to their preferences by choosing an alternative from each block, and afterwards assess each choice made through a scale of measurement. This means that, in this method the number of product alternative presented to the respondents is reduced, to be manageable for them, each experiment was divided in four blocks (randomized block designs to present four alternatives in each question). According to Battesini and Ten Caten (2005), the flexibility of this appproach allows the use of different models for estimating respondents trade-offs and preferences.

In step (e) the experimental design was chosen. Full or fractional factorials are usually applied to formulate and present a limited number of alternative products or services' descriptions from all possible combinations (GREEN; KRIEGER; WIND, 2001; LOUVIERE; TIMMERMANS, 1990). The $2^{\mathrm{k}}$ factorial was chosen to analyse attributes at two levels. A $2^{\mathrm{k}}$ factorial design is basically an experiment involving $\mathrm{k}$ factors, each of them with two levels (presence or absence of customized attributes). Afterwards, the relevant attributes and their levels should be combined into the factorial resulting alternatives, which are then presented to customers through prop cards. The prices of each product alternative and of the customized attributes are presented, in order to make the choice process more realistic.

The aim of a factorial experiment is to provide an estimate of the factor effects. This estimate indicates how each factor affects the process output so that the factors can be adjusted to optimize that output. The advantage of factorial experiments is that the effect of each factor on the output can be individual (the main effect of each factor) or be the result of interactions with other factors (interactive effects) (RAGHAVARAO; WILEY; CHITTURI, 2010). When assessing factor effects, one needs to consider not only the magnitudes of the effects, but their directions as well. The direction of an effect determines which factors need to be adjusted in order to optimize the process output. For further reading on factorial experiments, see Montgomery (2001). Subsequently, the product alternatives were defined according to the configurations of the proposed attributes resulting from the experimental design.

Afterwards, step (f) consisted in interviewing a sample of customers, who have purchased housing units recently. Those customers make general judgments of the resulting alternatives according to their preferences or choice likelihood (GREEN; WIND, 1975; LOUVIERE; TIMMERMANS, 1990). The sample of respondents was chosen from a specific target market which had a homogenous socio-economic profile. The application of the questionnaire was based on the decisions made in step (d) and (e), with the combination of choice and ranking. First, each respondent chose a preferred alternative in each block, and afterwards the alternatives were ranked. The researchers took notes during the interviews, as some respondents described their decision-making process, including reasons for choosing one product alternative over another.

Finally, in step (g), the results of the survey were analysed with the support of the SPSS 18 software. The analysis included a descriptive data analysis to provide an overview of customers' preferences in rankings of product attributes and product alternatives. Subsequently, the overall assessment, resulting from the survey, must be decomposed into separated utility scales by models used to infer partial values (worth) for each attribute level, with the purpose of predicting customers choice among alternatives (GREEN; KRIEGER; WIND, 2001; GREEN; WIND, 1975). Thus, a logistic regression model was developed to express the relevance of the customizable attributes assessed. The forward method for attribute selection was used, which supports the entry of every attribute in the model.

The logistic regression was chosen to be used in the proposed method, because this is a powerful technique of statistical modelling of categorical variables (HOSMER JUNIOR; LEMESHOW, 1989; EVERITT, 1992). This type of regression consists of models for relating a categorical response variable to explanatory variables that influence the occurrence of a specific event (HOSMER JUNIOR; LEMESHOW, 1989; EVERITT, 1992). The response variable (either nominal or ordinal) often represents a dichotomy, although sometimes it can represent more than two levels of response, while the explanatory variables can be either categorical or represent a continuum. 
In this study, the model's variable response is based on the simple choice questions. Furthermore, as the attributes are categorical variables and the variable is a binary response, logistic regression models were selected. In those models, category 1 represents "respondent selected the option" and category 0 represents "respondent did not select the option". In other words, the variable response can be interpreted as the probability of the alternative being selected when the attribute "Aj" is customized.

Moreover, the model output is usually expressed as a probability of occurrence. The logistic regression model provides an Odds Ratio (OR), which means the ratio of chances of choosing a specific product alternative that has some specific attributes over the product alternatives that do not have those attributes (HOSMER JUNIOR; LEMESHOW, 1989; EVERITT, 1992). According to those authors, this type of model uses the logit transformation (odds neperian logarithm) to avoid getting a negative value for the function that is obtained.

\section{Results \\ Preparation}

Table 1 presents the list of customizable attributes that were considered to be the most relevant ones by the customers, and also economically feasible from the perspective of the company, which is the main outcome of the preparation step. These attributes were categorized and organized hierarchically, from generic constructs to specific requirements. The process of organizing and categorizing attributes was based on an understanding on the nature of customer requirements, and enabled the application of conjoint analysis by displaying prompt cards in a survey with potential buyers.

\section{Selection of attributes and definition of attribute levels}

Table 2 presents a description of each category of customizable attributes, which can be considered as packages to be offered by the company as alternatives for customization. The two levels $(+1$ and -1$)$ indicate if the category of attributes is either customized or not in the product by their presence or absence. This figure summarizes the results of steps (b) and (c).

\section{Choice of the experimental design and type of measurement scale}

The attributes and their levels were combined to create product alternatives, and a price for each one of them was defined. The price variable was not included in the analysis, as it was used only to provide a more realistic weighing for the product alternatives by showing this information to customers during data collection. This means that the product alternatives prices simply avoided the situation in which customers choose an ideal product alternative without thinking about additional costs. The price estimates of those alternatives were based on existing cost data available in the company.

Table 1 - Customizable attributes organized into categories

\begin{tabular}{|c|l|}
\hline \multirow{2}{*}{ Finishing materials } & Colours \\
\cline { 2 - 2 } & Ceramic tiles \\
\cline { 2 - 2 } & Gypsum ceiling \\
\cline { 2 - 2 } & Stairs finishing materials \\
\hline \multirow{2}{*}{ Bathroom metal fixtures } & Toilet fittings \\
\cline { 2 - 2 } & Sink metal fittings \\
\hline \multirow{2}{*}{ Layout } & Bedroom with a bathroom \\
\cline { 2 - 2 } & kitchen counter between kitchen and living room \\
\cline { 2 - 2 } & Subtract wall between kitchen and laundry room \\
\hline \multirow{2}{*}{ Extensions (additions) } & Barbecue area \\
\cline { 2 - 2 } & Closed back yard (with roof) \\
\hline \multirow{2}{*}{ Electrical services } & Change voltage \\
\cline { 2 - 2 } & Add or move outlets \\
\hline Furniture & Cabinets both in the kitchen and bathroom \\
\hline
\end{tabular}




\begin{tabular}{l|c|c}
\hline \multicolumn{1}{c|}{ Description of the categories of attributes } & \multicolumn{2}{c}{ Levels } \\
\cline { 2 - 3 } & $\begin{array}{c}\text { Presence of } \\
\text { customized } \\
\text { attributes }\end{array}$ & $\begin{array}{c}\text { Absence of } \\
\text { customized } \\
\text { attributes }\end{array}$ \\
\hline $\begin{array}{l}\text { Electrical Services: change voltage; add or modify outlets; and add air } \\
\text { conditioning outlet }\end{array}$ & +1 & -1 \\
\hline $\begin{array}{l}\text { Spatial flexibility: holes in concrete structure for fireplace and barbecue; plan } \\
\text { for adding an extra room in the backyard; and modification of bathroom } \\
\text { entrance to access it directly from the bedroom }\end{array}$ & +1 & -1 \\
\hline $\begin{array}{l}\text { Furniture: kitchen counter between kitchen and living room; kitchen and } \\
\text { bathroom cabinets; and different metals }\end{array}$ & +1 & -1 \\
\hline $\begin{array}{l}\text { Finishing materials: floor and stairs finishings; different wall colours and } \\
\text { gypsum ceiling; and ceramic tiles in the kitchen and bathroom }\end{array}$ & +1 & -1 \\
\hline $\begin{array}{l}\text { Price: addition of 7\% in }+1 \text {, or subtraction of 7\% in -1 (based on the analysis } \\
\text { of data from the company's sales department) }\end{array}$ & +1 & -1 \\
\hline
\end{tabular}

The factorial design was then blocked to reduce the number of product alternatives to be assessed by respondents at the same time, in order to facilitate the application of the questionnaire. According to Louviere, Hensher and Swait (2000), fractioning or blocking implies in presenting only a fraction of the total number of product alternatives to customers. This fraction is usually chosen in a way that some higher order interactions between attributes may be confused with the main terms (i.e. the attributes themselves) or other interactions in the final model. Therefore, some preference information is lost upon fractioning. Blocking implies in presenting all product alternatives but not to the same respondent (LOUVIERE; HENSHER; SWAIT, 2000). For collecting data, the 32 profiles were blocked into two subsets of 16 product alternatives. Each subset was once more blocked in four different blocks and presented in a different questionnaire. In Table 3, some examples of blocks consisting of four product alternatives are presented.

Furthermore, the choice measurement scale and two-step stimulation method was adopted in this research, because it avoids showing too many product alternatives at once by blocking and, at the same time, allows the preference of customers to be assessed from more options than in traditional ways of blocking. This means that, in the second step, the respondent confirms his preference by choosing one among four product alternatives chosen in the first step blocks, without being overwhelmed by too many product alternatives.

\section{Data collection from a sample of customers}

The target population in this case study were homebuyers from the lower middle-class housing market, for which the company developed projects. As it was easier to contact customers that had recently purchased a house, rather than potential homebuyers, the decision was made to select a sample of customers from three projects recently delivered, and for whom customization options were offered. The population considered for this study were 59 customers who had recently bought and customized their housing units. A probabilistic sample was defined as a proportion of the population to be generalized (MALHOTRA, 2006). The calculation of the sample size was based on a $95 \%$ confidence level with a 0.12 margin of error, resulting in 32 customers. The sampling technique used in the case study was a stratified random sample, which consists of dividing the population into proportional smaller groups, or strata. Each stratum is formed by members that share a specific attribute or characteristic. For further information about this sampling procedure, see Bolfarine and Bussab (2007). A random sample from each stratum was then selected. This technique was used because questionnaires were applied to customers from three different housing schemes, and the sample was stratified accordingly. The number of respondents in each project is presented in Table 4.

In data collection, the two step stimulation process was applied by presenting the product alternatives to customers as follows:

(a) one block with four product alternatives was presented and the customer had to choose his preferred one; and

(b) this process was repeated four times with the same customer, until completing 16 product alternatives shown in 4 blocks. 
As a result, 4 preferred product alternatives (one from each block) were obtained. These 4 product alternatives were shown again to the customer, and he or she was asked to rank the alternatives in order of preference: from the most preferred to the least preferred. The interviewer wrote down the chosen sequence for each block, as well as the final ranking.

Figure 1 presents one block of different product alternatives, which is displayed in a prompt card. Different colours were used to facilitate visualization. Also, an explanatory sheet describing each attribute was given to customers.

Table 3 - Product alternatives for blocks 01 and 02

\begin{tabular}{|c|c|c|c|c|c|}
\hline \multicolumn{6}{|c|}{ Block 01} \\
\hline $\begin{array}{c}\text { Product } \\
\text { alternatives }\end{array}$ & $\begin{array}{l}\text { Electrical } \\
\text { Services }\end{array}$ & $\begin{array}{c}\text { Spatial } \\
\text { Flexibility }\end{array}$ & Furniture & $\begin{array}{l}\text { Finishing } \\
\text { materials }\end{array}$ & Price \\
\hline C25 & -1 & -1 & +1 & -1 & $\mathrm{R} \$ 3,720$ \\
\hline C26 & -1 & +1 & -1 & -1 & $\mathrm{R} \$ 3,210$ \\
\hline C27 & +1 & -1 & +1 & +1 & $\mathrm{R} \$ 12,555$ \\
\hline C28 & +1 & +1 & -1 & +1 & $\mathrm{R} \$ 13,375$ \\
\hline \multicolumn{6}{|c|}{ Block 02} \\
\hline $\begin{array}{c}\text { Product } \\
\text { alternatives }\end{array}$ & $\begin{array}{l}\text { Electrical } \\
\text { Services }\end{array}$ & $\begin{array}{c}\text { Spatial } \\
\text { Flexibility }\end{array}$ & Furniture & $\begin{array}{l}\text { Finishing } \\
\text { materials }\end{array}$ & Price \\
\hline E13 & +1 & -1 & -1 & -1 & $\mathrm{R} \$ 930$ \\
\hline E14 & -1 & -1 & +1 & -1 & $\mathrm{R} \$ 4,280$ \\
\hline E15 & +1 & +1 & -1 & +1 & $\mathrm{R} \$ 11,625$ \\
\hline E16 & -1 & +1 & +1 & +1 & $\mathrm{R} \$ 16,585$ \\
\hline
\end{tabular}

Table 4 - Number of respondents in each project

\begin{tabular}{c|c|c|c|c}
\hline & \multicolumn{3}{|c|}{ Housing Projects } & \\
\hline \multirow{2}{*}{$\begin{array}{c}\text { Sample } \\
\text { Size }\end{array}$} & $\mathrm{A}$ & $\mathrm{B}$ & $\mathrm{C}$ & Total \\
\cline { 2 - 5 } & 10 & 13 & 9 & 32 \\
\hline
\end{tabular}

Figure 1 - Example of prompt card containing four product profiles from one block

\begin{tabular}{|c|c|c|c|c|}
\hline \multicolumn{5}{|c|}{ GROUP B } \\
\hline \multirow[b]{2}{*}{$\begin{array}{c}\text { Electrical } \\
\text { installations }\end{array}$} & & \multirow[b]{2}{*}{ Furniture } & & ADDITIONAL PRICE \\
\hline & & & & $R \$ 4,650.00$ \\
\hline \multirow{4}{*}{$\begin{array}{c}\text { Electrical } \\
\text { installations }\end{array}$} & & & \multirow[b]{2}{*}{$\begin{array}{l}\text { Finishing } \\
\text { materials }\end{array}$} & ADDITIONAL PRICE \\
\hline & & & & $\mathrm{R} \$ 8,835.00$ \\
\hline & \multirow[b]{2}{*}{$\begin{array}{c}\text { Spatial } \\
\text { flexibility }\end{array}$} & \multirow[b]{2}{*}{ Furniture } & & ADDITIONAL PRICE \\
\hline & & & & $R \$ 7,490.00$ \\
\hline & \multirow[b]{2}{*}{$\begin{array}{c}\text { Spetial } \\
\text { Flexibility }\end{array}$} & & \multirow[b]{2}{*}{$\begin{array}{l}\text { Finishing } \\
\text { materials }\end{array}$} & ADDITIONAL PRICE \\
\hline & & & & $R \$ 12,305.00$ \\
\hline
\end{tabular}

\section{Results and discussion}

In Figure 2, the percentages represent the relative frequency of customers that have chosen the product alternative in order of priority, from the most to the least preferred (first to fourth place), according to the presence or absence of customized attributes. This graph can be regarded as an overview of customers' preferences towards the product alternatives, which can provide support to the definition of product alternatives to be offered by the housebuilding company. For instance, it shows that the electrical services package appears mostly in the product alternative chosen as a third option (by 56\% of interviewees) or in the product alternative ranked as the fourth option (50\%), meaning 
that this package could be offered to this specific type of client. Spatial flexibility appears mainly in the product alternative chosen as first option (72\%). Furniture appears mainly in the fourth product alternative (63\%), but also in the second product alternative (59\%). Finally, finishing materials appears mainly in the alternative chosen as third (66\%) and fourth (66\%) options; however, it also appears in the other product alternatives, both 59\% on the first and on the second one.

The first choice of interviewees portrays the preference for the presence of spatial flexibility with the frequency of $72 \%$, then finishing materials with 59\%, furniture with 53\% and electrical services with $38 \%$. Therefore, this type of analysis produces information on the product alternatives that must be offered to customers, and the range of customizable attributes to be considered by housebuilding companies in their solution space definition. Another example of interpretation of these percentages is the composition of the ideal solution space to this sample of customers, by considering the first position on the different customizable attributes. For instance, in this case, the solution space offered to the general audience could include customized spatial flexibility, furniture and finishing materials.

Figure 3 presents customers' preferences for each selected attribute. The finishing materials and spatial flexibility categories were the most preferred customizable attributes, pointed out by $63 \%$ and $62 \%$ of customers, respectively. It is noteworthy that most of the customers preferred the standardized alternative of electrical services attribute (Figure 3). However, $46 \%$ of the interviewees would like to customize electrical services, so this customizable attribute could be offered to a specific group of clients, allowing the company to offer different solution spaces to diverse groups of customers according to their specific needs.

The notes taken during the interviews provided some insights regarding customers' decision making on product alternatives. For instance, some customers have justified their preference for electrical services because these would be more difficult to change after occupancy. Other customers have chosen finishing materials, so they would be able to move in with everything already in place. A major reason for preferring spatial flexibility was that customers were used to have barbecues on weekends, while furniture was considered important because this was something that they had to do anyway in a near future. It was also observed that the price had a strong influence in customers' decisions. The customers that faced financial difficulties when buying a housing unit usually excluded expensive attributes, or the ones that were less important for them, or even the ones that were important but that could be changed after project delivery, once they have finished paying the dwelling. A few other customers chose as many attributes as the housing loan allowed them to, while others had some savings to invest in the improvement of the product, considering the additional attributes offered by the company. These examples of how price was considered when making a choice indicates that conjoint analysis is effective for understanding the trade-off analysis made by customers in decision-making, as suggested by Granja et al. (2009). Furthermore, in mass-customized housing this is especially relevant for establishing the boundaries of the solution space, considering customers' financial constraints.

In this study a binary logistic regression model was used, in which the response variable represents a dichotomy. This dichotomy is represented by the presence or not of each customized product attributes in order to estimate the effect of those attributes (e.g. electrical services, spatial flexibility, furniture and finishing materials) on the choice of customers and their preferences.

The logistic regression model output showed that the first attribute included in the model was finishing materials, and the second was spatial flexibility. The inclusion of other attributes did not have statistical significance. Table 5 presents the results of the logistic regression model, indicating that spatial flexibility and finishing materials attributes contributed significantly (p-value $<0,01$ ) for customers to choose product alternatives in which these attributes were available. The inclusion of spatial flexibility as an important customizable element for customers corroborates the results obtained by Schoenwitz et al. (2017). Additionally, the relevance of finishing materials can be related to findings from Hentschke et al. (2014) in other projects from the same housebuilding company, such as:

(a) significant impact in customers' satisfaction;

(b) a high frequency of choice for customizable attributes related to finishing materials offered by the construction company in the design stage; and

(c) high occurrence of changes made after occupancy in finishing materials.

These results reinforce the relevance of offering customizable attributes related to spatial flexibility and finishing materials in the development or refinement of housing solution spaces. 
Figure 2 - Ranking of attribute preferences

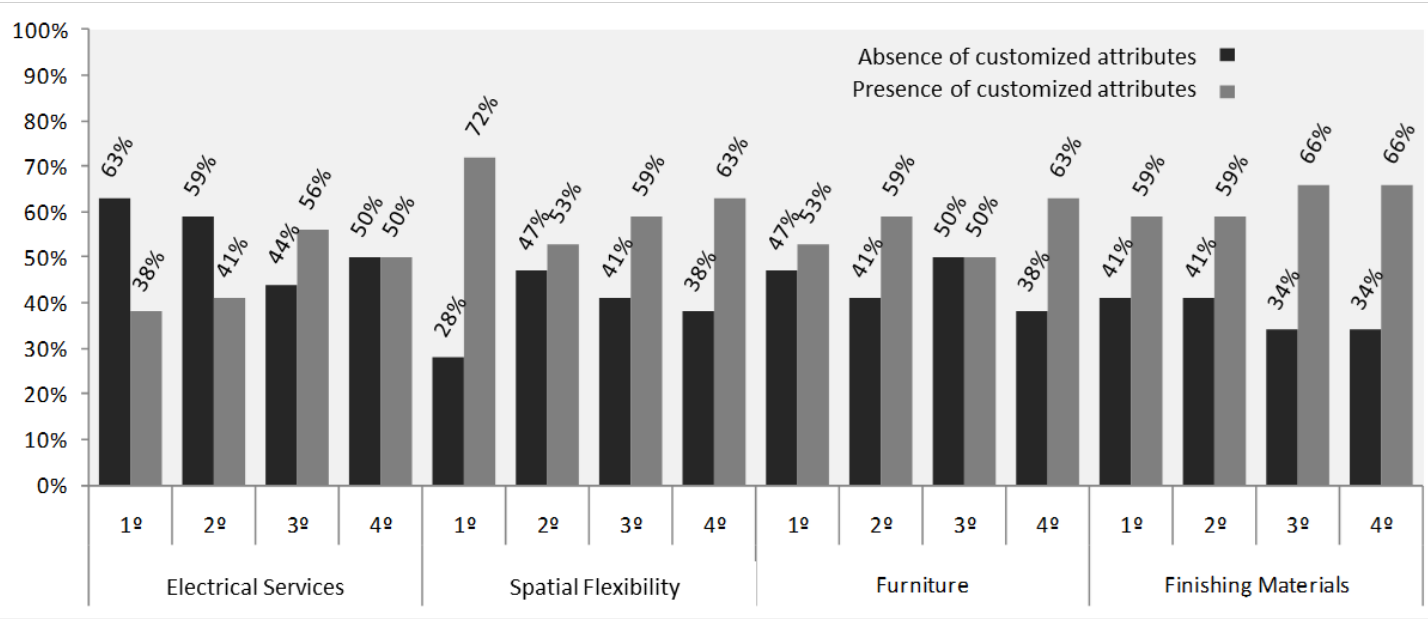

Figure 3 - Customers stated preference for customized attributes or not

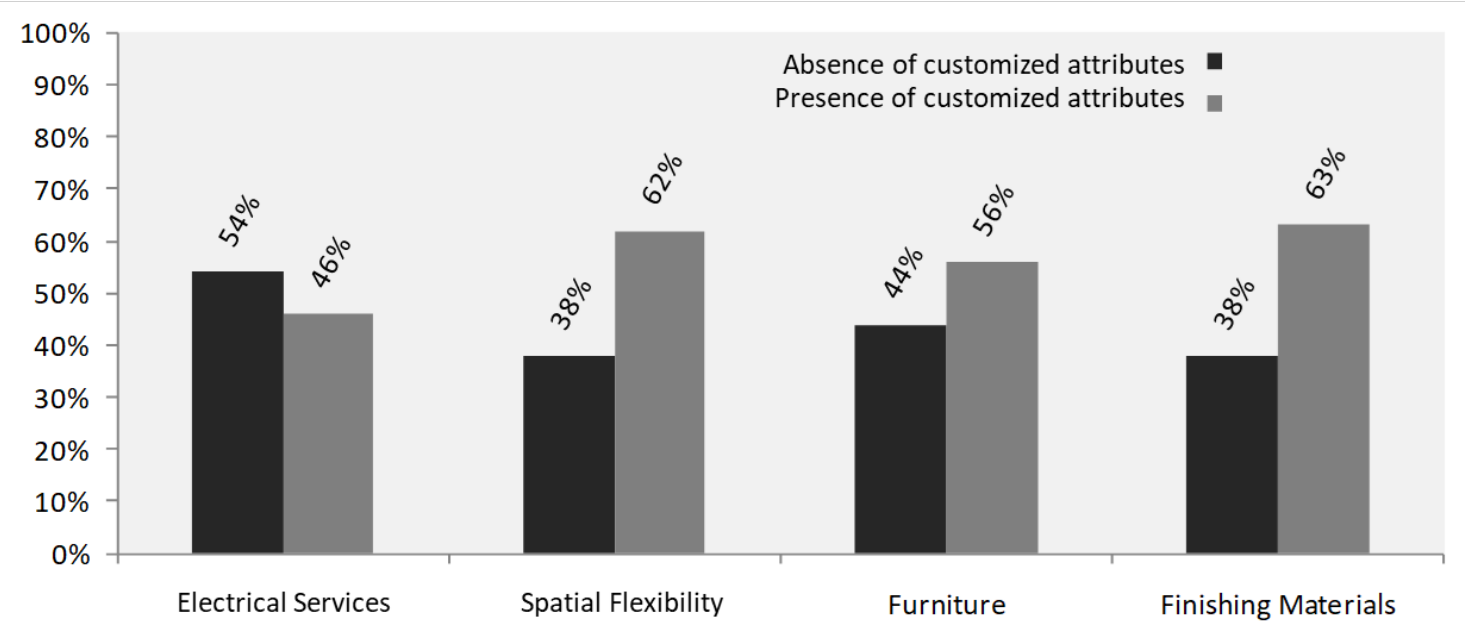

Table 5 - The logistic regression model output

\begin{tabular}{c|c|c|c|c|c|c}
\hline Factor & B & S.E. & Sig. & OR & \multicolumn{2}{c}{ CI (95\%) OR } \\
\hline Spatial flexibility & 0.6480 & 0.2110 & 0.0021 & 1.9117 & 1.2641 & 2.8910 \\
\hline $\begin{array}{c}\text { Finishing } \\
\text { materials }\end{array}$ & 0.6909 & 0.2114 & 0.0011 & 1.9954 & 1.3184 & 3.0200 \\
\hline Constant & -1.8231 & 0.2052 & 0.0000 & 0.1615 & & \\
\hline
\end{tabular}

Note:

B: estimated logit coefficient;

S.E.: Standard error of the coefficient;

Sig.: Significance level of the coefficient;

OR: Odds ratio; and

$\mathrm{Cl}$ : Confidence interval.

Equation 1 expresses the relationship between the ranking of the product alternative and the presence of customized attributes. Therefore, results show that the presence of customized finishing materials and flexibility packages influences the choice of product alternatives, as both are considered to have statistical significance at $5 \%$ (p-value $<0.001)$. In this case, the coefficients represent users' preference. If the customized attribute "finished materials" is offered in the product alternative, its probability of being chosen increases by 0,6908. Likewise, the presence of the "spatial flexibility" customized attribute increases by 0,6480 the 
probability of choice. These results may support decision making by the product development team to offer product alternatives associated with the target market (Eq. 1).

Probability of choice of product alternative $=-1.8231+0,6908$ finishing materials $+0,6480$ spatial flexibility Eq. 1

\section{Conclusions}

This paper has proposed the use of the conjoint analysis technique to identify customer preferences regarding customized attributes in low-cost housing projects. All the steps that are necessary for modelling the customers' preferences regarding customization of low-income housing projects have been described. The adaptation of conjoint analysis to this specific problem involved the use of three statistical methods:

(a) different sources of data, from different project stages should be used to define a consistent list of customizable attributes to be considered;

(b) the two step stimulation conjoint analysis technique proposed by Battesini and Ten Caten (2005) was applied to simulate a realistic consumption process. The main advantage of this is the flexibility for using different models to estimate respondents trade-offs and preferences;

(c) product alternatives were developed by using a $2^{\mathrm{k}}$ factorial design then fractioned in two 16 sets of alternatives and in four blocks in order to reduce the number of alternatives to be analysed by each customer (or potential homebuyer) diminishing the choice complexity; and

(d) logistic regression models were used to relate the response variable (ranking of product alternative) and the explanatory variables (whether customization packages were included or not).

This adaptation of the conjoint analysis method was developed and tested in a case study, carried out in a smallsized company that offered some degree of customization in housing projects. The conjoint analysis was relatively simple to be used, due to the fact that the company had a well-structured customer database. The outcomes of that technique can provide valuable information to support decision making in the product development process, the ranking of customization packages to be offered by the company (i.e. solution space). The combination of qualitative and quantitative data can be considered as a positive aspect of this research work, as some useful metrics have been proposed, and these can be complemented by information that provide an in-depth understanding of customers' preferences in the selection of customizable attributes.

Therefore, conjoint analysis can potentially contribute to the choice of product attributes that are capable of increasing the overall customers' perceived value of products. For companies offering limited product customization, the application of this technique enables managers to make more informed decisions when facing the trade-off between product variety and production costs.

Some limitations of this investigation must be pointed out: (a) due to a relatively small sample size, it was not possible to analyse the interactions between attributes, or to compare the preferences of different customer profiles; (b) no analysis have been made on how much the customers were willing to pay for each attribute, i.e. the price was given only as a support to choose product alternatives; and (c) the customizable attributes had to be categorized, i.e. by grouping several items in single headings, due to the limited number of product alternatives feasible to be considered by customers during choice.

Therefore, future studies on the use of conjoint analysis for understanding customer preferences in mass customized housing should explore the interactions between customizable attributes, as well as customers' willingness to pay. Another opportunity for further research is to compare the use of conjoint analysis with other alternative statistical methods and techniques, such as paired comparison-based preference measurement, that do not reduce so much the range of customization alternatives that are considered in the simulation of the decision-making process. Furthermore, there is still a need for flexible mechanisms to enable the configuration of questionnaires for capturing housing preferences, based on given answers and previous knowledge on customer profiles, as suggested by Freitas (2000) and Fogliatto and Da Silveira (2008).

\section{References}

BARLOW, J. From craft production to mass customisation ? Customer-focused approaches to housebuilding. In: INTERNATIONAL GROUP FOR LEAN CONSTRUCTION, 6., Guarujá, 1998. Proceedings [...] Guarujá: IGLC, 1998.

BARLOW, J.; OZAKI, R. Achieving 'Customer Focus' in private housebuilding: current practice and lessons from other industries. Housing Studies, v. 18, n. 1, p. 87-101, 2003. 
BATTESIni, M.; TEN CATEN, C. S. Análise conjunta com estimulação em duas etapas. Produto e Produção, v. 8, p. 31-51, 2005.

BHARATI, P.; CHAUDHURY, A. Using choiceboards to create business value. Communications of the ACM, v. 47, n. 12, p. 77-81, 2004.

BOLFARINE, H.; BUSSAB, W. O. Elementos de amostragem. São Paulo: Editora Edgard Blucher, 2007.

BRANDLI, L. L.; HEINECK, L. F. M. As abordagens dos modelos de preferência declarada e revelada no processo de escolha habitacional. Ambiente Construído, Porto Alegre, v. 5, n. 48, p. 61-75, out./dez. 2005.

BRANDSTETTER, M. C. G. de O. Análise do comportamento dos clientes do mercado imobiliário com ênfase na mobilidade, escolha e satisfação residenciais. Florianópolis, 2004. Tese (Doutorado em Engenharia) - Departamento de engenharia de produção e sistemas, Universidade Federal de Santa Catarina, Florianópolis, 2004.

BRANDSTETTER, M. C. G. de O. et al. Diretrizes de marketing imobilário a partir da investigação do ciclo de vida familiar. In: Conferencia Internacional da Lares, 13., São Paulo, 2013. Anais... São Paulo, 2013.

CASTRO, M. C. P.; SHIMBO, L. Z. O “Padrão Econômico” da habitação: construindo uma trajetória de mercado. In: ENCONTRO NACIONAL DA ANPUR, 14., Rio de Janeiro, 2011. Anais... Rio de Janeiro, 2011.

DAVIS, S. Future perfect. Reading: Addison-Wesley, 1987.

DE MEDEIROS, J. F.; RIBEIRO, J. L. D.; CORTIMIGLIA, M. N. Influence of perceived value on purchasing decisions of green products in Brazil. Journal of Cleaner Production, v. 110, p. 158-169, 2016.

DU, X.; TSENG, M. M. Characterizing customer value for product customization. In: ASME DESIGN ENGINEERING TECHNICAL CONFERENCE, Las Vegas, 1999. Proceedings... Las Vegas, 1999.

EVERITT, B. S. The analysis of contingency tables. $2^{\text {nd }}$. ed. London: Champman \& Hall, 1992

FERGUSON, S. M.; OLEWNIK, A. T.; CORMIER, P. A review of mass customization across marketing, engineering and distribution domains toward development of a process framework. Research in Engineering Design, v. 25, n. 1, p. 11-30, 2014.

FOGLIATTO, F. S.; DA SILVEIRA, G. J. C. Mass customization: a method for market segmentation and choice menu design. International Journal of Production Economics, v. 111, n. 2, p. 606-622, feb. 2008.

FOGLIATTO, F. S.; DA SILVEIRA, G. J. C.; BORENSTEIN, D. The Mass customization decade: an updated review of the literature. International Journal of Production Economics, v. 138, n. 1, p. 14-25, jul. 2012.

FORMOSO, C.; LEITE, F.; MIRON, L. Client requirements management in social housing: a case study on the residential leasing program in Brazil. Journal of Construction in Developing Countries, v. 16, n. 2, p. 47-67, 2011.

FREITAS, A. A. F. de. Segmentação do mercado imobiliário utilizando dados de preferência declada. Florianópolis, 2000. Tese (Doutorado em Engenharia) - Departamento de engenharia de produção e sistemas, Universidade Federal de Santa Catarina, Florianópolis, 2000.

FREITAS, A. A. F. de. Modelagem comportamental dos decisores através de técnicas de preferência declarada: uma aplicação no setor imobiliário de Florianópolis-SC. Florianópolis, 1995. Tese (Mestrado em Engenharia) - Departamento de engenharia de produção e sistemas, Universidade Federal de Santa Catarina, Florianópolis, 1995.

FREITAS, A. A. F. de; HEINECK, L. F. M. Linhas de pesquisa no estudo do comportamento do consumidor: da mobilidade residencial à avaliação pós-ocupação. Ambiente Construído, Porto Alegre, v. 3, n. 1, p. 25-33, jan./mar. 2003.

FRUTOS, J. D.; BORENSTEIN, D. A framework to support customer-company interaction in mass customization environments. Computers in Industry, v. 54, n. 2, p. 115-135, jun. 2004.

GERARD, K.; SHANAHAN, M.; LOUVIERE, J. Using stated preference discrete choice modelling to inform health care decision-making: a pilot study of breast screening participation. Applied Economics, v. 
35, p. 1073-1085, 2003.

GILMORE, J. H.; PINE II, B. J. The four faces of mass customization. Harvard Business Review, v. 1, p. 91, feb. 1997.

GRANJA, A. D. et al. A natureza do valor desejado na habitação social. Ambiente Construído, Porto Alegre, v. 9, n. 2, p. 87-103, abr./jun. 2009.

GREEN, P. E.; KRIEGER, A. M.; WIND, Y. Thirty years of conjoint analysis : reflections and prospects. Interfaces, v. 31, n. 3, p. 56-73, 2001.

GREEN, P. E.; SRINIVASAN, V. Conjoint analysis in consumer research: issues and outlook. Journal of Consumer Research, v. 5, n. 2, p.103-123, 1978.

GREEN, P. E.; WIND, Y. A new way to measure consumer judgments. Harvard Business Review, jul. 1975.

GREENE, M.; ORTÚZAR, J. D. D. Willingness to pay for social housing attributes: a case study from Chile. International Planning Studies, v. 7, p. 55-87, 2002.

HART, C. W. L. Mass customization: conceptual underpinnings, opportunities and limits. International Journal of Service Industry Management, v. 6, n. 2, p. 36-45, 1995.

HENTSCHKE, C. S. et al. A method for proposing valued-adding attributes in customized housing. Sustainability, v. 6, n. 12, p. 9244-9267, 2014.

HOSMER JUNIOR, D.W.; LEMESHOW S. Applied logistic regression. Massachusetts: John Wiley \& Sons, 1989.

KOWALTOWSKI, D. C. C. K. et al. A critical analysis of research of a mass-housing programme. Building Research \& Information, v. 3218, May, 2018.

KOWALTOWSKI, D. C. C. K.; GRANJA, A. D. The concept of desired value as a stimulus for change in social housing in Brazil. Habitat International, v. 35, n. 3, p. 435-446, 2011.

LINNER, T.; BOCK, T. Evolution of large-scale industrialisation and service innovation in japanese prefabrication industry. Construction Innovation, v. 12, n. 2, p. 156-178, 2012.

LOUVIERE, J. J.; HENSHER, D. A., SWAIT, J. D. Stated choice methods: analysis and applications. Port Chester: Cambridge University Press, 2000.

LOUVIERE, J.; TIMMERMANS, H. hierarchical information integration applied to residential choice behavior. Geographical Analysis, v. 22, n. 2, p. 127-144, 1990.

MADDEN, G. Experimentation in economics: an overview of the stated-preference experimental design method. Australian Economic Papers, v. 34, n. 64, p. 120-135, 1995.

MALHOTRA, N. K. Pesquisa de marketing: uma orientação aplicada. 4. ed. Porto Alegre: Bookman, 2006.

MOLIN, E. J. E. Conjoint Analysis. In: THE MEASURMENT and analysis of housing preference and choice. [s.l: s.n.]. 2011. cap. 6, p. 127-156.

MOLIN, E. J. E.; OPPEWAL, H.; TIMMERMANS, H. J. P. Analyzing heterogeneity in conjoint estimates of residential preferences. Journal of Housing and the Built Environment, p. 267-284, 2001.

MONTGOMERY, D. C. Design and analysis of experiments. New York: Wiley, 2001.

NAHMENS, I.; BINDROO, V. Is customization fruitful in industrialized homebuilding industry? Journal of Construction Engineering and Management, v. 137, n. 12, p. 1027-1035, 2011.

NOGUCHI, M. Japanese prefabricator's means to commercialize mass custom homes equipped with photovoltaic solar electric systems. In: PROCEEDINGS of the ACSA 2005 International Conference. p. 2529, 2005.

NOGUCHI, M.; HERNÁNDEZ-VELASCO, C. R. A ‘Mass Custom Design’ approach to upgrading conventional housing development in Mexico. Habitat International, v. 29, n. 2, p. 325-336, jun. 2005.

ORZECHOWSKI, M. A.; ARENTZE, T. A.; BORGERS, A. W. J. Alternate methods of conjoint analysis 
for estimating housing preference functions : effects of presentation style. Journal of Housing and the Built Environment, p. 349-362, 2005.

PILLER, F. T. Mass customization : reflections on the state of the concept. The International Journal of Flexible Manufacturing Systems, v. 16, p. 313-334, 2004.

PINE II, B. J. Personalizando produtos e serviços : customização maciça. São Paulo: Makon Books do Brasil, 1994.

RAGHAVARAO, D.; WILEY, J. B.; CHITTURI, P. Choice-based conjoint analysis: models and design. New York: Chapman \& Hall/CRC, Taylor \& Francis Group, 2010.

ROCHA, C. G. da. A conceptual framework for defining customisation strategies in the housebuilding sector. Porto Alegre, 2011. Tese (Doutorado em Engenharia) - Escola de Engenharia, Universidade Federal do Rio Grande do Sul, Porto Alegre, 2011.

SALVADOR, F.; HOLAN, P. M. de; PILLER, F. Cracking the code of mass customization cracking the code of mass customization. MIT Sloan Management Review, v. 50, n. 50315, p. 70-78, 2009.

SCHOENWITZ, M. et al. Product, process and customer preference alignment in prefabricated house building. International Journal of Production Economics, v. 183, p. 79-90, 2017.

SCHOENWITZ, M.; NAIM, M.; POTTER, A. The nature of choice in mass customized house building. Construction Management and Economics, v. 30, p. 203-219, abr. 2012.

SILVA, E. F. et al. Em busca de habitabilidade : adequações inseridas em um conjunto habitacional a partir do processo. In: ENCONTRO NACIONAL DE TECNOLOGIA DO AMBIENTE CONSTRUÍDO, Juiz de Fora, 2012. Anais... Juiz de Fora, 2012.

SILVEIRA, G. da; BORENSTEIN, D.; FOGLIATTO, H. S. Mass customization : literature review and research directions. International Journal Production Economics, v. 72, n. 49, p. 1-13, 2001.

SONG, J.; JANG, T.; SOHN, S.Y. Conjoint analysis for IPTV service. Expert Systems with Applications, v. 36, n. 4, p.7860-7864, 2009.

SQUIRE, B. et al. Mass customization: the key to customer value? Production Planning \& Control, v. 15, n. 4, p. 459-471, jun. 2004.

TILLMANN, P. A.; FORMOSO, C. T. Opportunities to adopt mass customisation: a case study in the brazilian house building sector. In: ANNUAL CONFERENCE OF THE INTERNATIONAL GROUP FOR LEAN CONSTRUCTION, 16., Manchester, 2008. Proceedings... Manchester, 2008.

UNTERSCHULTZ, J.; QUAGRAINIE, K. K.; VINCENT, M. Evaluating Quebec's preference for alberta beef versus US beef. Agribusiness, v. 13, 457-468, 1997.

VON HIPPEL, E. Economics of product development by users: the impact of 'sticky' local information. Management Science, v. 44, n. 5, p. 629-644, may 1998.

WOODRUFF, R. B. Customer value: the next source for competitive advantage. Academy of Marketing Science Journal, v. 25, n. 2, p. 139-153, Spring 1997. 


\section{Cynthia dos Santos Hentschke}

Programa de Pós-Graduação em Engenharia Civil: Construção e Infra-Estrutura | Universidade Federal do Rio Grande do Sul | Av. Osvaldo Aranha, 99, 70 andar, sala 706 | CEP 90035-190 | Porto Alegre - RS - Brasil | Tel.: (51) 3308-4848 | E-mail: cynthiahentschke@gmail.com

\section{Patrícia André Tillmann}

Department of Real Estate | University of California San Francisco | 654 Minnesota St. 2 ${ }^{\text {nd }}$. Floor | San Francisco - CA - USA | 94013 | Tel.: $+1(650)$ 439-9552 | E-mail: patriciatillmann@gmail.com

\section{Carlos Torres Formoso}

Programa de Pós-Graduação em Engenharia Civil: Construção e Infra-Estrutura | Universidade Federal do Rio Grande do Sul | E-mail: formoso@ufrgs.br

\section{Vera Lúcia Milani Martins}

Matemática, Estatística e Física | Instituto Federal de Edução, Ciência e Tecnologia do Rio Grande do Sul | Rua Coronel Vicente, 281, Centro Histórico | Porto Alegre - RS - Brasil | CEP 90030-041| Tel.: (51) 3930-6002 | E-mail: vera.martins@poa.ifrs.edu.br

\section{Maria Elisa Soares Echeveste}

Departamento de Estatística, Programa de Pós-Graduação em Engenharia de Produção | Universidade Federal do Rio Grande do Sul | Rua Osvaldo Aranha, 99 | Porto Alegre - RS - Brasil | CEP 90035-190 | Tel.: (51) 3308-1986 | E-mail: echeveste@producao.ufrgs.br

\section{Ambiente Construído}

Revista da Associação Nacional de Tecnologia do Ambiente Construído

Av. Osvaldo Aranha, 99 - 3o andar, Centro

Porto Alegre - RS - Brasil

$$
\text { CEP } 90035-190
$$

Telefone: +55 (51) 3308-4084

Fax: +55 (51) 3308-4054

www. seer. ufrgs. br/ ambienteconstruido

E-mail: ambienteconstruido@ufrgs.br 